\title{
Learning Lessons from the Economic Crisis in Self-employment
}

\author{
Alfonso Jesús Torres Marín
}

ABSTRACT The main objective of this article is to test the hypothesis that the economic crisis has resulted in significant changes in the socioeconomic and labor profile of the new self-employed in Spain between 2008 and 2013. Additionally, it is intended to determine if there are homogeneous profiles of new self-employed workers that allow to set clusters, and, if so, to check how these clusters have changed in the studied period. To verify the above-mentioned hypotheses, it has been carried out a descriptive analysis followed by a Cluster Analysis, using the Continuous Sample of Working Lives data. The research concludes that the economic recession has been accompanied by a fall in the number of new self-employed between 2008 and 2013, along with a significant change in their socio-demographic and occupational profile. There is also evidence of the existence of several clusters of self-employed, with heterogeneous sociodemographic and labor characteristics. The composition and features of these clusters evolved in parallel to the economic situation, showing an intense increase in the educational level and a reduction in the job stability between 2008 and 2013.

KEY WORDS: entrepreneurship, self-employment, economic crisis, Business cycle, self-employed workers profiles

JEL Classification: E32, J21, M13

ESIC Business and Marketing School, Spain

\section{Introduction}

Self-employment is changing because of the acceleration of the outsourcing process of auxiliary services in companies (Guadaño, et al., 2010). Labor precariousness, together with the success of some entrepreneurial experiences in more technologically advanced sectors, constitutes a breeding ground for it (McCarthy et al., 2018). The Spanish business structure which consists mainly of micro SMEs (Maroto, 2006) or the exis-

Correspondence concerning this article should be addressed to: Alfonso Jesús Torres Marín, ESIC Business and Marketing School, Avenida de Valdenigrales s/n, Pozuelo de Alarcón 28223. Madrid, Spain. E-mail: alfonso.torres@esic.edu tence of previous family experiences as self-employed (Sánchez, 2006) also facilitate the development of selfemployment.

In recent years, self-employment has been gaining ground as a job-generating element in the European Union, from being a solution to unemployment, to becoming a factor linked to dynamic, innovative and job-creating business projects (Cueto \& Taboada, 2004). This reinforces the idea that its origin is not as much associated to necessity as to opportunity (Global Entrepreneurship Monitor [GEM], 2018). Entrepreneurs are the revitalizing sap of the European economy (Calleja \& Crespo, 2013). Entrepreneurship leads to higher productivity and economic growth. Entre- 
preneurs are inclined to work more hours and more efficiently, given that their income depends on their performance (Carree \& Thurik, 2010).

Recently developed activities facilitate new self-employment, whereas traditional methods have a negative impact. (Roura, et al., 2005).

Due to the important role played by the self-employed and micro-enterprises in the production of goods and services in our country, the Spanish economy is more vulnerable, both in terms of employment and productivity, to the economic downturn. Microenterprises are more dependent on changes in the economic situation and in the labor market (Haltiwanger et al., 2010).

On many levels, self-employment is the seed of entrepreneurship. For this reason, although the central objective of this paper is self-employment, it will be used with some frequency bibliography and information referred to entrepreneurship as a point of support.

The main purpose of this article is to test the hypothesis that the economic crisis has derived in significant changes in the socioeconomic and labor profile of the new self-employed in Spain between 2008 and 2013. With this objective in mind, the data contained in the Continuous Sample of Working Lives (CSWL) is used as the main source of information.

The CSWL is an organized set of anonymous microdata extracted from Spanish administrative records, both of the Social Security and the Continuous Municipal Register. The raw data refers to just over a million people and concerns a representative sample of all the people who had a relationship with Social Security in a given year.

Additionally, using the same source of information, this study intends to determine if there are enough homogeneous profiles of new self-employed workers to obtain clusters with similar occupational and socioeconomic characteristics and, besides, to precise if these have changed during the study period in case of existing.

Although there are multiple studies in the economic literature on the impact of the economic cycle on selfemployment/entrepreneurship - which are described in the theoretical framework - there is a research gap to be filled owing to the fact that these studies do not analyze the effects that the economic cycle has on the socio-economic and labor profiles of new self-em- ployed, grouping them in a reduced number of clusters, and using a large volume of reliable data for it.

This paper is structured as follows: Part 2 presents the theoretical framework, including a brief reference to the theoretical approaches to entrepreneurship and further introduces relevant economic literature on selfemployment and business cycle; next section presents the methodology and data used. Part 4 characterizes the empirical setting, describing the economic impact of the crisis on firms and self-employment in Spain; finally, the results, conclusions and limitations of this research, as well as future possible investigations lines, are presented in Sections 5 to 7.

\section{Theoretical Framework}

\subsection{Approaches to Entrepreneurship}

Entrepreneurship is presented using various names such as business factor, business function, entrepreneurial initiative, entrepreneurial behavior, or even entrepreneurial spirit. The business factor refers to a new productive factor different from the classic capital, labor and land, which is scarce and therefore must be remunerated through the entrepreneur income. The consideration as a business function refers to the discovery and exploitation of opportunities, as well as the creation of companies. Entrepreneurial behavior is understood as one that succeeds in combining innovation, risk-taking and proactivity (Miller, 1983). It also covers the classical theories of the innovative entrepreneur (Schumpeter, 1934, 1942), the entrepreneur who takes risks and occupies a position of uncertainty (Knight, 1921; Fairlie, 1999), and the entrepreneur who takes the initiative, has imagination and creates new opportunities (Sanders \& Nee, 1996). Entrepreneurial initiative encompasses risk taking, renewal or innovation within or outside an existing organization (Öberg, 2019). Entrepreneurial spirit emphasizes that, while managers focus on the exploitation of business opportunities, entrepreneurs focus on exploration, search and innovation.

Entrepreneurial project includes the identification and evaluation of opportunities, the decision to exploit them or sell them, the obtaining of resources, the development of strategy, as well as organization of the new business project (Eckhardt \& Shane, 2003). Entrepreneurship is the process through which individuals - alone or within an organiza- 
Table 1. Theoretical approaches to the entrepreneurial function.

\begin{tabular}{|c|c|c|c|c|}
\hline $\begin{array}{l}\text { Theoretical approach } \\
\text { / Level of analysis }\end{array}$ & Economic approach & $\begin{array}{l}\text { Psychological } \\
\text { approach }\end{array}$ & $\begin{array}{c}\text { Socio-cultural or } \\
\text { institutional approach }\end{array}$ & Managerial Approach \\
\hline \multirow[t]{4}{*}{ Micro (Individual level) } & $\begin{array}{c}\text { Entrepreneur } \\
\text { function as a factor of } \\
\text { production }\end{array}$ & Personality traits theory & Marginalization theory & $\begin{array}{c}\text { Liebeinstein efficiency } \\
\text { theory }\end{array}$ \\
\hline & $\begin{array}{l}\text { Entrepreneur's benefit } \\
\text { theory }\end{array}$ & $\begin{array}{c}\text { Psychodynamic theory } \\
\text { of the entrepreneur's } \\
\text { personality }\end{array}$ & Role theory & $\begin{array}{l}\text { Entrepreneur's } \\
\text { behavioral theory }\end{array}$ \\
\hline & $\begin{array}{c}\text { Occupational choice } \\
\text { theory }\end{array}$ & & Network theory & $\begin{array}{l}\text { Models of company } \\
\text { creation process }\end{array}$ \\
\hline & & & & $\begin{array}{l}\text { Alternatives to } \\
\text { becoming an } \\
\text { entrepreneur }\end{array}$ \\
\hline \multirow[t]{3}{*}{ Meso (firm level) } & Transaction cost theory & & Network theory & $\begin{array}{c}\text { New company's sucess } \\
\text { models }\end{array}$ \\
\hline & & & Incubator theory & $\begin{array}{c}\text { Models of generation } \\
\text { and development } \\
\text { of innovative } \\
\text { projects "corporate } \\
\text { entrepreneurship" }\end{array}$ \\
\hline & & & Evolutionary theory & \\
\hline \multirow[t]{4}{*}{$\begin{array}{l}\text { Macro (global or } \\
\text { regional level of the } \\
\text { economy) }\end{array}$} & $\begin{array}{c}\text { Schumpeter theory } \\
\text { of economic } \\
\text { development }\end{array}$ & $\begin{array}{l}\text { Kizner entrepreneur } \\
\text { theory }\end{array}$ & $\begin{array}{c}\text { Weber's economic } \\
\text { theory }\end{array}$ & \\
\hline & $\begin{array}{c}\text { Theory of the } \\
\text { endogenous regional } \\
\text { development }\end{array}$ & & Social change theory & \\
\hline & & & $\begin{array}{c}\text { Occupational } \\
\text { population theory }\end{array}$ & \\
\hline & & & Institutional theory & \\
\hline
\end{tabular}

tion - pursue opportunities (Stevenson \& Jarillo, 1990).

The fundamental activity of entrepreneurs is business creation, and this can be studied at the level of individuals and / or groups - analyzing psychological aspects and social variables, education, training or family - or at an environmental level, either from the variables that facilitate business development, or analyzing aspects of the economic, social and cultural environment (Kolvereid \& Isaksen, 2006). This has given rise to many theoretical approaches that comprehend the different theories of the entrepreneurial function and the creation of companies, which are summarized in Table 1 (Veciana, 1999). Entrepreneurship is a recur- ring theme in the academic and business world due to several reasons like: (1) organizations require people with an entrepreneurial profile to face the challenges of an increasingly dynamic and complex business context; (2) the economic crisis and the slowdown in the growth of Western economies, added to the growth of emerging countries, require the emergence of business projects that sustain and create a new business fabric that guarantees social welfare and (3) the development of information technologies in general and Internet in particular has led to the birth of new sectors and business models driven by a new generation of entrepreneurs (Sentana et al., 2018). Under these circum- 
stances, it is quite probable a change in the profile of the entrepreneurs and self-employed, and, as a consequence, different groups of them can be found according to these characteristics, as it is hypothesized in this paper.

This new economic and social context has led to recover the Schumpeterian concept of entrepreneurship, understood as a process of "destructive creation" and engine of socioeconomic development (Schumpeter, 1934, 1942). In accordance with this concept, the entrepreneur is the person who makes new combinations of the means of production, giving rise to innovations in products and processes that promote technological and social change. A significant part of economic growth in the future depends on this ability to support the growth of new entrepreneurs.

Given than the main goal of this paper is to test the hypothesis that the economic crisis has resulted in significant changes in the socioeconomic and labor profile of the new self-employed in Spain between 2008 and 2013, I will focus now on a brief review of the literature on the relationship between entrepreneurship/selfemployment and economic cycle.

\subsection{Entrepreneurship/Self-employment and Business Cycle}

There is an ongoing discussion about whether business cycles influence entry rates to entrepreneurship (Congregado et al., 2012; Kollinger \& Thurik 2012; Parker et al., 2012), and if this influence is pro-cyclical or counter-cyclical.

A previous question to be answered is why selfemployment/start-up activity should be related to business cycles. As seen in Table 1, research shows a variety of reasons why people start their own business. At a micro level, several researches find that demographic, educational, economic, and personality characteristics may affect the decision to start a new business. At a macroeconomic level, factors like the general business climate, unemployment level, or the availability of jobs opportunity are important. From the economic point of view, it is relevant to understand the impact of this macroeconomic factors in the entry rates of entrepreneurship, and if this entry rates varies pro or counter cyclically.

Three main macroeconomic variables may affect entrepreneurial entry in the economic literature: GDP, unemployment and interest rates.

Some research suggests that when GDP grows, the start-up rates increase, due to the optimism about the future, and, thus, economy grows in terms of demand and investment. According to this reasoning, during the periods of recession there would be fewer people liable to be self-employed, because future appears uncertain and investment is perceived as risky (Rampiny, 2004; Lee, 2018). Barley (2007) indicates that during growth periods entrepreneurs may introduce radical innovation, which may lead to further growth and entrepreneurship opportunities. Aforementioned research considers the fact that economic growth has a pro-cyclical effect on entrepreneurship. However, some researchers consider exactly the opposite. For example, Francois and Lloyd Ellis (2003) conclude that innovative entrepreneurs may prefer to enter the market when the cost are low, which may occur in a recession. Therefore, the impact of the GDP on entrepreneurship may differ depending on which effect prevails.

The second relevant macroeconomic factor is the unemployment level, which reflects the availability of opportunities in the dependent employment. According to occupational choice model (Parker, 2018), people may change from employment or unemployment to self-employment if this is more rewarding than their current situation. If both the unemployment benefits and duration are low, then people have more incentives to become self-employed during periods of high unemployment. Accordingly, the number of start-ups will keep low in periods of low unemployment rates when people have plenty of jobs opportunities in the labor market. This means that the unemployment has counter-cyclical effects over self-employment/new business creation.

Other researchers, such as Roman et al., (2013) combine unemployment and GDP factors. Their hypothesis is that high unemployment may have different effects on the types of entries, showing that new business created by unemployed are more opportunity driven during boom periods and motivated by necessity during recessions. They consider that if the business fails and have to shut down, finding employment will be easier in a low unemployment context. Both arguments weaken the counter-cyclical effect making the relationship between unemployment and self-employment/ entrepreneurial entry ambiguous. 
The third relevant factor is the interest rates. Low interest rates during recessions make the cost of capital lower and may stimulate new business creation. The opposite happens during the boom periods, particularly, if the new ventures need large amounts of capital (Parker, 2018).

Summarizing, from a theoretical point of view several macroeconomic forces affect new business formation (or self-employment) but these are pulling in different directions. It is unclear which of these effects prevails. Several authors argue that forces could be different for different types of entrepreneurs. If entry is dominated by opportunity entrepreneurs, the impact of economic growth should be larger than if it is driven by necessity ones.

The review of the previous research on the effect of demand, unemployment and interest rates on the creation of new business/self-employment poses an empirical question concerning the predominant effect (Hamilton, 2000). The existing evidence is scarce and inconclusive. Regarding the relationship between GDP growth and the creation of new companies, some studies suggest a positive relation (Grant, 1996; Carrasco, 1999) for USA and Spain respectively. However, Perotin (2006) and Parker (2009) do not find that cyclical relation.

Torres (2018) states that the business cycle in Spain has a more intense effect - both in expansion and recession - on the employed workers than on self-employed (García-Fernández et al., 2018). Caceres and Fernández (2009) developed two analytical models using time series in relation to economic activity (GDP) and affiliation to Social Security - both in the general regime and as self-employed - to establish that the general regime presents a greater rigidity to the variations of the activity and therefore it grows in expansive times whereas it falls in recessive times.

The findings of the empirical relation between unemployment and entrepreneurship are also contradictory and may vary according to the period-analyzed (Parker, 2018). Blanchflower (2000) analyzed this relationship in the OECD countries finding a positive relation in only two countries, while the relation between the level of unemployment and entrepreneurship is negative in the rest of the countries. Hundt and Sternberg (2014) found a positive relationship between unemployment and the propensity to engage in new ventures in the case of Germany during the recent economic crisis.

Several authors have studied the effects of the economic crisis on entrepreneurship and it is linked with the economic recovery. Some of them suggest that reduced economic growth, or recession, diminishes entrepreneurial opportunities and innovation (Koellinger \& Thurik, 2012; Parker et al., 2012; Klapper \& Love, 2011; Willians \& Vorley, 2015). Others consider that the economic crisis is a catalyst with the ability of motivating innovation and entrepreneurial spirit out of necessity because of the fact that the opportunity cost is lower in these periods (Simón-Moya et al., 2016; Filipetti \& Archibugi, 2010; Brunjes \& Revilla, 2013).

Svaleryd (2015) shows that although the local business cycle is less important for total self-employment rates in Sweden, there are heterogeneous effects across groups. People with higher human capital endowments are more likely to be pulled into self-employment, while those with lower human capital endowments are to a larger extent pushed into self-employment (Abubakar et al., 2019).

Fritschet al.,(2016) research concerning Germany state that: (1) the effects of deviations in the unemployment rate and in GDP from their long-term trend on new business formation level tend to be counter-cyclical; (2) This counter-cyclical relationship is mainly due to significantly lower levels of entry into self-employment during periods when unemployment is below its long-term trend. Unemployment above the trend does not induce significantly higher levels of new business formation, pointing to a certain asymmetry (Megeirhi, 2018). These counter-cyclical effects make it clear that poor economic conditions seem to encourage transitions into entrepreneurship. At the same time, these results reveal that there is no evidence of a stimulating effect of boom periods on self-employment.

Konon et al., (2018) analyze for German regions whether start-up rates in different industries are systematically changed by business cycle variables. Using a unique data set at the industry level, they mostly find correlations that are consistent with counter-cyclical influences of the business cycle on entries in both innovative and non-innovative industries (Ryan \& Daly, 2019). Entries into the large-scale industries, including the innovative part of manufacturing, are only influenced by changes in the cyclical component of unem- 
ployment, while entries into small-scale industries, like knowledge intensive services, are mainly influenced by changes in the cyclical component of GDP.

Schweitzer and Shane (2016) demonstrate that, in the case of USA, changes in demand conditions substantially influence the marginal rate of transition into and out of self-employment from other labor market states, after considering demographic and industrial differences. A contraction in demand has a large effect on self-employment because it alters the balance between self-employment entry and exit. Falling demand drives to an increase in the rates of entrepreneurship exit, however, it has countervailing effects on entry. While a decrease in demand leads to a decrease in the opportunity cost of entry into entrepreneurship by increasing the rate of unemployment, the entry into entrepreneurship is higher from employment than from unemployment or from out of the labor market. Finally, they state that the effect of changes in demand on selfemployment is different for incorporated and unincorporated self-employment.

To sum up, there is a number of possible reasons for the effect of business cycle on new business formation. However, the empirical evidence is inconclusive. We may also conclude that despite the multiple studies on the impact of business cycle over self-employment and entrepreneurship, there is a research gap because these studies do not analyze the effects which business cycle has on the socio-economic and labor profile of new self-employed.

\section{Methodology and Sample}

To verify the research hypotheses, an analysis by segments has been carried out, using a non-causal methodology - cluster analysis - in order to detect profiles of new self-employed at two different moments in time. In the same way, a descriptive analysis to know its typology has been conducted. This allows the current study to delve into self-employed specific and detailed characteristics so to understand what its evolution has been. The source of information for this analysis was the Continuous Sample of Working Lives.

The application of the cluster analysis techniques allows not only to describe the socio-occupational profile of new self-employed at different moments of time, but also to determine the possible existence of a dynamic of change involved coinciding with the downturn of the Spanish economy, which makes the cluster analysis a very appropriate methodology for the purpose of the paper.

In order to complement the previous analysis, a regression analysis has also been incorporated. It facilitates a better understanding of the impact of the economic cycle on self-employment in Spain from a macroeconomic perspective. This is a methodology commonly used in the economic literature to quantify the effect of the variations of the GDP or the unemployment rate on self-employment. The period selected (2005 - 2015) aims to capture the impact before, during and after the downturn. The estimation methodology used was Ordinary Least Squares (OLS). The data were obtained from the Spanish National Institute of Statistic.

\subsection{The New Self-employed in the Continuous Sample of Working Lives (CSWL)}

The Continuous Sample of Working Lives is an organized set of anonymous micro data extracted from administrative records, from both Social Security and the Municipal Continuous Register. The data refers to more than one million individuals and constitutes a representative sample of all the people who had a relationship with Social Security in a given year. The sample of each year consists of four out of every hundred people who take part of the reference population. Therefore, the elevation factor is 25 .

The starting point to determine the new self-employed workers for the year 2013 (or 2008) is the set of people of the CSWL whose contribution regime is between one of the following 521, 522, 540, 721, 740, 825,840 .

To have the largest number of observations for Spain, all people who had been self-employed in the year of study (either 2008 or 2013) were analyzed, but this does not imply that the last labor episode was selfemployment. What really matters is if they were selfemployed in the year of study (2013 or 2008) and their working trajectory until that year.

Next, the self-employed who accomplished the following requirements were selected:

1. - Contribution Regime: 521.

2. - Economic sector different from fishing and agriculture.

3. - Date of registration as self-employed. 
3.1. After $1 / 1 / 2011$ and end-date of self-employment (if any) later than 1/1/2013 (for the 2013 analysis).

3.2. After $1 / 1 / 2006$ and end-date of self-employment (if any) later than 1/1/2008 (for the 2008 study).

4. - Once the self-employment has begun, the employment relationship is considered in the three reference years $(2011 / 2012 / 2013)$ or $(2006 / 2007 / 2008)$. It is established as a criterion that they must not combine their activity as self-employed neither with working for others, nor having successive periods of registering and deregistering as self-employed within the 3 years of reference. Additionally, a flexibility clause has been established, allowing an overlap of 15 days of work as self-employed with work for others to cover the situation in which the person leaves the company and the legal 15 days are given for it.

With the above criteria in mind, 32,413 new selfemployed workers were selected in 2008 and 29,274 in 2013.

\subsection{Cluster Analysis Methodology}

For the cluster analysis, it has been used the Continuous Sample of Working Lives (CSWL) of the years 2008 and 2013. To establish the clusters there were considered 20 socio-economic and labor variables calculated for 10 economic sectors. They are listed in Table 2.

The analysis has been exclusively limited to individuals of Spanish nationality (26.065 in 2008 and 24.118 on 2013), given that the CSWL offers limited historical socioeconomic and labor information for non-nationals.

To create the clusters, and check their consistency, two different techniques have been considered: Ward's hierarchical method to determine the number of clusters and non-hierarchical reassignment method by KMeans to decide which sectors compose every cluster.

The economic sectors used in the analysis come from the National Classification of Economic Activities and the twenty variables selected widely represent the labor and socioeconomic profile of the self-employed.

After defining each variable, it the mean has been calculated for all the self-employed in every sector.

The use of cluster analysis allows not only to describe the labor and sociodemographic profile of the new selfemployed workers at different moments of time, but also to determine the possible existence of a dynamic of change on these as a result of the economic crisis. Based on these premises, it may be considered that
Cluster Analysis is the most suitable method to achieve the proposed research objectives, since it allows the creation of segments (profiles of self-employed) very similar internally and very different from each other.

In fact, I consider that the combination of the proposed objectives and the methodology used constitutes a relevant contribution to research in the field of selfemployment and economic cycle in Spain, allowing to understand in a better manner the impact of the economic crisis on the sociodemographic and labor characteristics of the different self-employed segments

\section{Empirical Setting Characterization: the Origin of the Economic Crisis (2008-2013) and its Impact on Firms and Self-employment}

Since the end of 2008, the Spanish economy witnessed a dramatic deterioration of all its economic indicators. This generated a situation of pessimism derived from the lack of confidence of the different economic agents, families, and companies - and within these mainly SMEs, which resulted in a drastic reduction in credit, a contraction of economic activity and an increase in unemployment.

Many entrepreneurs, especially self-employed, were forced to close their businesses and those who remained had to reinvent themselves and internationalize (Dunn \& Holtz-Eakin, 2000). Between 2008 and 2013 more than 345,000 SMEs (INE-DIRCE, 2016) and 315.000 self-employed (MTMSS, 2018) disappeared from the economic scenario in net terms - around $10 \%$ of the business and $15 \%$ of the selfemployed workers. According to INE (2018), Spanish real GDP per capita fell by $7.3 \%$, unemployment rate increased from $13.8 \%$ to $25.7 \%$ and public debt raised from $39.4 \%$ of GDP to $93.7 \%$. The current account balance went from a deficit of $-9.3 \%$ of GDP to a surplus of $1.4 \%$, reflecting the remarkable export effort of firms.

The building sector was the one that suffered the adjustment the most, followed by the sale of vehicles. The impact was different for self-employed that for employed workers. The number of senior self-employed fell in favor of new self-employed workers (less than 3 years old), who represent a third of the total. The proportion of women, elders, Spanish, and representatives of the service sector grew between 
Table 2. Socioeconomic and labor variables and economic sectors considered in the cluster analysis.

\begin{tabular}{|c|c|}
\hline Socioeconomic variables & Working life variables \\
\hline $\begin{array}{l}\text { V1 }=\text { Number of self-employed } \\
\text { V2 }=\text { Percentage of university graduatees } \\
\text { V3 }=\text { Percentage of men } \\
\text { V4 }=\text { Average age as of December 31,2008 }\end{array}$ & 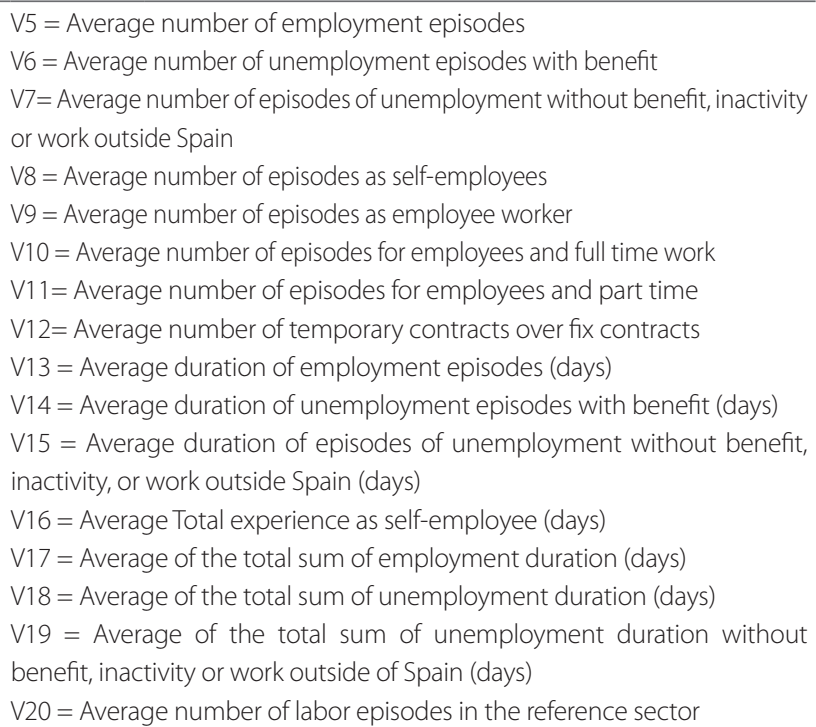 \\
\hline
\end{tabular}

Economic sectors (National classification of economic activities) (CNAE)

\begin{tabular}{ll}
\hline 1. Manufacturing industry & 6. Hostelry \\
2. Commerce and trade and repair of motor vehicles & 7. Transportation, warehousing and communication \\
3. Financial services & 8. Other social activities and common services \\
4. Real state and services to companies & 9. Education \\
5. Construction & 10. Health \\
Note: The sectors analyzed have been reduced to ten due to the non-consideration of agriculture and fishing and the \\
elimination of sectors with a non-existent or almost nul representation of new self-employed workers such as the extractive \\
industry, production and distribution of electricity, gas and water, defense, etc.
\end{tabular}

them. Self-employment has also allowed women to improve their employment position by being able to access management positions and having a greater presence in sectors that were traditionally occupied by men (Cuadrado et al., 2004).

So, we have some clear indications which points out that sociodemographic and occupational profiles of new self-employed could have been affected in recent years, as is hypothesized in this research.

\section{Results}

In the subsection 5.1, the results of the lineal regression analysis are presented, in order to get a better understanding of the impact of the economic cycle on self-employment in Spain from a macroeconomic perspective. As mentioned before, this is a methodology commonly used in economic literature to quantify the effect of both the variations of the GDP or the unemployment rate on self-employment.

After that, in the subsections 5.2 and 5.3 the results of the analysis on the evolution of the new self-employed workers profile in Spain during the period 2008-2013 are presented, using the CSWL of both years as main source of information. In subsection 5.2, the focus is on the conclusions obtained from the descriptive analysis of data, while the sub- 
section 5.3 reveals the results of the cluster analysis for each of the years.

\subsection{Impact of the Economic Cycle on Self- employment: An Econometric Approach}

Through econometric models estimated in this research for the period 2005-2015 in Spain, it is possible to confirm a positive relationship between the real GDP growth rate and the variation rate of self-employed - see Model 1 in Table 3 - and also a negative relationship between the unemployment rate and the number of self-employed - see Model 2 in Table 3.

Based on the coefficients estimated in the two models, it may be concluded that, on average, for each percentage point of real GDP growth, the number of self-employed increased by $0.56 \%$, and for each point of unemployment rate reduction, almost 19.000 new self-employed were generated. Therefore, we may conclude that there is a pro-cyclical impact of the business cycle on self-employment.

Although the results obtained in both models are reasonable - see test in Table 3-, it is necessary to maintain certain precautions in regard to their goodness and interpretation, due to the reduced number of observations, as well as the possible existence of relevant variables omitted, which could generate a bias in the estimations of the parameters.

\subsection{Changes in the Occupational and Sociodemographic Profile of New Self-employed Workers}

After exhaustively analyzing the profile of new selfemployed workers in 2008 and 2013, the main conclusions obtained are presented.

There are nearly $10 \%$ less new self-employed in 2013 than in 2008. Given the elevation factor of the CSWL, it means the creation of 78,475 less new self-employed jobs in the 2011-2013 triennium - 50,475 of which would be national and 28,000 non-nationals.

There has been a moderate fall in the number of Spanish new self-employed (-7.7\%), along with a more intense drop in the number of foreigners (-17.8\%). Especially affected are the citizens of Eastern Europe, with a decrease of $58.3 \%$, due to their dedication to the construction sector. Individuals from the EU-15 decreased by $22 \%$, while Chinese $(+61.6 \%)$ and nationals of African countries (+26.8\%) increased considerably.
There was a 1.6 percentage drop of new self-employed male workers. For Spanish nationals the difference in age between men and women was shortened to half a year, compared to 2 years in 2008.

In 2013, Spanish self-employed workers were mainly involved in the commerce and car trade and repair sectors, $30.3 \%$, followed by real estate activities and business services, $15.8 \%$, hostelry sector $15.7 \%$ and construction $10.8 \%$. It stands out that $60 \%$ of the Chinese self-employed and 52\% of the African's perform their activity in the commerce and 36\% of Eastern European citizens in the construction sector.

On the one hand, the activities with the greatest drop in the number of new self-employed workers were construction $(-53.9 \%)$, followed by manufacturing $(-21.4 \%)$ and transport, warehousing and communication $(-18.4 \%)$. On the other hand, the largest increases occurred in education (50.5\%), commerce (13.6\%) and hospitality (12.1\%). Therefore, construction lost its prevalent position for non-nationals, in favor of the hospitality sector followed by transportation, and retail commerce.

There exist predominantly male activities (construction, transport, warehousing, communication and manufacturing) and other mainly female sectors (health, social services and education).

Spanish and citizens from the EU-15 show the highest levels of education $-26 \%$ of the first and $29 \%$ of the latter were graduates in 2013-.

The crisis has shown the importance of the education as an effective instrument to improve skills and labor opportunities. In general, it is detected a higher level of studies in the self-employed regardless of their nationality, sector of activity, sex and region of residence. In fact, the percentage of graduates increased between 2008 and 2013, from $9.1 \%$ to $24.7 \%$. This was motivated by: (1) a significant reduction in the activity in both the construction and industrial sectors in parallel with an increase in the services sector, which generally requires a higher level of education; (2) a high unemployment rate that has frequently affected highly educated people and has led them to seek other job opportunities as self-employed, and (3) nationals of some countries, especially those with lower education -essentially workers from the construction sector- have sought fewer opportunities as self-employed workers, partly returning to their country. In addition, 
Table 3. Regression analysis results.

Model 1 - OLS Regression between variation rate of self-employed workers (Y) and Real GDP Growth.

\begin{tabular}{lcccc}
\hline \multicolumn{2}{c}{ Dependent variable $Y$} & -variation rate of seif-employed workers & & \\
\hline \multicolumn{1}{c}{ Variable } & Coefficient & Standard deviation & $\boldsymbol{t}$ statistic & $\boldsymbol{p}$ value \\
\hline Constant & -0.0142 & 0.0054 & -2.217 & .054 \\
$\mathrm{X}=$ GDP growth & 0.5667 & 0.2365 & 2.396 & \\
R-Squared $=0.389$ & R-Square Corrected $=$ & & & \\
$\mathrm{F}(1.9)=5.74$ & 0.321 & & \\
\end{tabular}

Model 2 - OLS Regression between number of self-employed workers ( $Y$ ) and unemployment rate (X) in Spain. Period 2005-2015.

\section{Dependent variable Y - number of seif-employed workers}

\begin{tabular}{|c|c|c|c|c|}
\hline Variable & Coefficient & Standard deviation & t statistic & $p$ value \\
\hline Constant & $2.38 \mathrm{e}+06$ & 21604 & -110.2 & $2.1 \mathrm{e} 15$ \\
\hline $\begin{array}{l}X=\text { Unemployment } \\
\text { rate }\end{array}$ & -18815.9 & 1143.9 & -16.4 & 5.05 e 8 \\
\hline R-Squared $=0.967$ & $\begin{array}{c}\text { R-Square Corrected }= \\
0.964\end{array}$ & & & \\
\hline$F(1.9)=270.5$ & $\begin{array}{c}\text { PValuee of F test }=5.05 \\
\text { e-08 }\end{array}$ & & & \\
\hline
\end{tabular}

\section{Test of heteroscedasticity, autocorrelation and normality of residuals}

\begin{tabular}{|c|c|c|c|}
\hline Test & Model 1 & Model 2 & Conclusions \\
\hline $\begin{array}{l}\text { Heterocedasticity Constrast of } \\
\text { Breusch-Pagan }\end{array}$ & $\begin{array}{c}\text { Statistic of contrast } \\
\mathrm{LM}=0.0146 \text { critical value } \\
\text { Chi-square }(1) \text { with right tail } \\
\text { probability } 0.05=3.841\end{array}$ & $\begin{array}{c}\text { Statistic of contrast } \\
\text { LM=0.00109 critical value } \\
\text { Chi-square }(1) \text { with right tai } \\
\text { probability } 0.05=3.841\end{array}$ & $\begin{array}{c}\text { No } \\
\text { Heterocedasticity }\end{array}$ \\
\hline $\begin{array}{l}\text { First order autocorralation } \\
\text { contrast of Breusch-Codfrey }\end{array}$ & $\begin{array}{c}\text { Statistic of contrast } \\
L M F=0.635 \text { critical value } F( \\
\text { 1.8) with right tai probability } \\
0.05=5,317\end{array}$ & $\begin{array}{c}\text { Statistic of contrast } \\
\text { LMF=0.029 critical value } F(1.8) \\
\text { with right tal probability } \\
0.05=5.317\end{array}$ & $\begin{array}{c}\text { No } \\
\text { Autocorrelation }\end{array}$ \\
\hline $\begin{array}{l}\text { Jarque Bera test for normality } \\
\text { of residuals }\end{array}$ & $\begin{array}{l}\text { Contrast statistic: } \text { Chi- } \\
\text { square }(2)=0.696 \text { critical } \\
\text { va lue }(2) \text { with right tail } \\
\text { probability }(0.05)=5.991\end{array}$ & $\begin{array}{l}\text { Contrast statistic: } \text { Chi- } \\
\text { square }(2)=3.086 \text { critical } \\
\text { value }(2) \text { with right tail } \\
\text { probability }(0.05)=5.991\end{array}$ & Normal residuals \\
\hline
\end{tabular}


in certain sectors, such as education and health, there may have been a certain "expulsion effect" of the nongraduated self-employed by others highly educated.

In Spain, $17.6 \%$ of the new self-employed workers were not nationals in 2013. However, there was a wide dispersion in the different regions. In Balearic Islands and Melilla, three out of every ten new self-employed were non-nationals. The Canary Islands, the Community of Madrid, Catalonia, La Rioja and the Valencian Community followed it - where between 20\% and 25\% were foreigners. In contrast, in Extremadura and Galicia, self-employed workers of Spanish nationality exceeded $93.5 \%$.

The impact of the crisis has been very heterogeneous and dependent on the differences between territories. It has also been strongly connected to the activity developed in them.

Between 2008 and 2013, commerce gained relative ground in practically all territories, while construction lost much of its strength, and the hospitality sector occupied the second position in relevance.

The analysis of the evolution of various parameters of the working life shows an increase in labor instability of the new self-employed - evidenced by the increase of 2.1 episodes of employment per individual (from 11 to 13.1). New self-employed workers also had more work experience in the reference sector (4.9 compared to 4.6), although with shorter duration. Selfemployed women have reduced their age of entry into the labor market from 24.1 to 23.2 years.

Because of all the above-mentioned results, it may be concluded that there has been a significant change in the occupational and sociodemographic profile of new self-employed during the economic crisis, so the first hypothesis of this research is clearly confirmed.

\subsection{Self-Employment Socio-Economic and Occupational Clusters}

In 2008, four clusters of self-employment were generated. Tables $4 \mathrm{~A}$ and $4 \mathrm{~B}$ show respectively the sectors belonging to each one and the mean value of the different variables analyzed for each of them.

In Cluster 1, the percentage of graduates $(12.8 \%)$ is slightly lower than the mean value and the percentage of men is at the mean. Self-employed have greater job stability than the rest - fewer labor episodes, a lower ratio of temporary contracts and longer duration mean of each employment episode. In addition to this, they have a similar number of experiences as self-employed and accumulate fewer experiences in the reference sector.

Cluster 2 refers to self-employed who belong only to the construction sector. The percentage of university graduates is the lowest of all. Apart from being a very masculinized sector - 9 out of 10 self-employed are men - the number of labor episodes added to the ratio of temporary contracts are well above the mean, while the duration of each episode of employment is comparatively lower, so we can conclude that this sector presents a high labor instability. The members of this cluster accumulate 4 years of experience as selfemployed, the largest of all analyzed. Considering the number of labor episodes in the reference sector, new self-employed workers have had the greatest number of experiences (7.6 episodes) - $81 \%$ higher than the 4.2 reached in mean.

In Cluster 3, the percentage of graduates is only $5 \%$, which is much lower than the mean and the second lowest of all the clusters. The percentage of men is $53.3 \%$, coinciding with the mean. These individuals enjoy less employment stability, although it is clearly higher than that reflected in the cluster 2. Both the experience accumulated by them as self-employed and the number of labor episodes in the sector of reference are quite high.

It could be also observed in cluster 4 that the percentage of graduates is $32 \%$, the highest of all by large. It is the only cluster in which female representation is larger than male - only $33 \%$ of men-. It is constituted by the youngest self-employed, 36.9 years old compared to 38.4 at global mean. The working life of these individuals shows intermediate employment instability - between clusters 1 and 2. Their accumulated experience as self-employed, with only 2.8 years, is the lowest.

Table 4C summarizes the previous paragraphs, helping to understand the characteristics of each of the working groups based on their mean size, male representation, education level, job stability, experience in the sector of reference and experience as selfemployed

In 2013, three clusters are configured. In Table 5A and $5 \mathrm{~B}$ can be observed respectively the sectors and the mean value of the different variables analyzed 
Table 4. Cluster analysis in 2008: main results.

Table 4A — Sectors by cluster.

\begin{tabular}{|c|c|c|c|}
\hline Cluster 1 & Cluster 2 & Cluster 3 & Cluster 4 \\
\hline Manufacturing industry & Construction & Hostelry & Education \\
\hline $\begin{array}{l}\text { Commerce, vehicles sale and } \\
\text { reparation }\end{array}$ & & $\begin{array}{c}\text { Transportation, warehousing } \\
\text { and communication }\end{array}$ & $\begin{array}{c}\text { Health, veterinary activities } \\
\text { and social services }\end{array}$ \\
\hline Financial services & & $\begin{array}{c}\text { Other social activities and } \\
\text { community services }\end{array}$ & \\
\hline \multicolumn{4}{|l|}{$\begin{array}{l}\text { Real state and business } \\
\text { services }\end{array}$} \\
\hline 4 sectors (40\%) & 1 sector (10\%) & 3 sectors (30\%) & 2 sectors $(20 \%)$ \\
\hline 13.254 self-employees & 4.808 self-employees & 6.850 self-employees & 1.153 self-employees \\
\hline (50.9\%) & $(18.4 \%)$ & $(26.3 \%)$ & $(4.4 \%)$ \\
\hline
\end{tabular}

Table 4B — Profiles of new self-employed.

\begin{tabular}{|c|c|c|c|c|c|c|}
\hline & VARIABLES & Cluster 1 & Cluster 2 & Cluster 3 & Cluster 4 & Total \\
\hline V1 & Number of self-employees & 3.314 & 4.808 & 2.283 & 577 & 2.607 \\
\hline V2 & Percentage of university graduates & $12.80 \%$ & $2.00 \%$ & $5.00 \%$ & $32.00 \%$ & $13.20 \%$ \\
\hline V3 & Percentage of men & $53.80 \%$ & $89.00 \%$ & $53.30 \%$ & $33,50 \%$ & $53.10 \%$ \\
\hline V4 & Age as December 31, 2008 & 39.29 & 37.08 & 38.59 & 36,91 & 38.38 \\
\hline V5 & Number of employment episodes & 9 & 13.8 & 12.2 & 10,9 & 10.8 \\
\hline V6 & Number of unemployment episodes & 1.8 & 3 & 2.4 & 1,6 & 2.1 \\
\hline V8 & Number of episodes as self-employed & 1.7 & 1.8 & 1.9 & 1,7 & 1.8 \\
\hline V9 & Number of episodes as employee worker & 7.4 & 12 & 10.3 & 9,2 & 9.1 \\
\hline V12 & $\begin{array}{l}\text { Number of temporary contracts over fixed } \\
\text { contracts }\end{array}$ & 3.6 & 7.2 & 5.1 & 5,9 & 4.9 \\
\hline V13 & Duration of employment episodes (days) & 652.8 & 501 & 548.3 & 430 & 561.7 \\
\hline V14 & $\begin{array}{l}\text { Duration of unemployment episodes with } \\
\text { benefits (days) }\end{array}$ & 198.8 & 151 & 168.3 & 180 & 181.1 \\
\hline V16 & Total experience as self-employee (days) & 1299.50 & 1478.00 & 1470.70 & 1042.50 & 1317.30 \\
\hline V20 & $\begin{array}{l}\text { Number of labour episodes in the } \\
\text { reference sector }\end{array}$ & 3.2 & 7.6 & 4.6 & 4 & 4.2 \\
\hline
\end{tabular}


Table 4. Cluster analysis in 2008: main results (Continued).

Table 4C - Main characteristics of each cluster.

\begin{tabular}{lcccc}
\hline Cluster characteristic & Cluster 1 & Cluster 2 & Cluster 3 & Cluster 4 \\
\hline Size of the cluster & high & very high & low & very low \\
Male representation & medium & very high & medium & very low \\
Education level & medium & very low & very low & very high \\
Labour Stability & high & very low & low & medium \\
$\begin{array}{l}\text { Experience as self- } \\
\text { employed }\end{array}$ & medium & high & high & low \\
Experience in the sector & low & very high & medium & medium \\
\hline
\end{tabular}

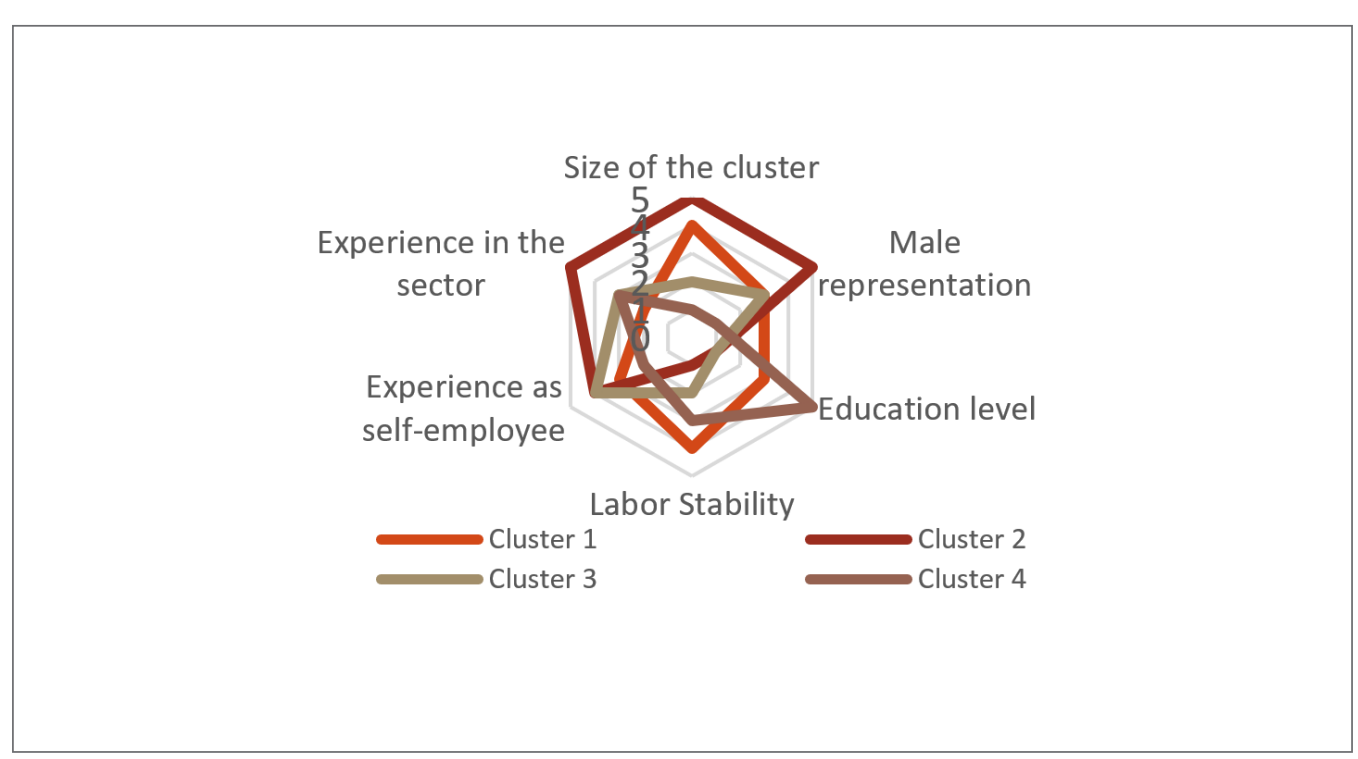

Figure 1. Cluster analysis diagram.

Source: Own elaboration based on MCVL year 2008 data.

for each of them. Table 5C summarizes the main characteristics of each cluster.

Focusing on the comparative analysis of the clusters in 2008 and 2013, some differences may be observed.

First, three conglomerates were created in 2013, compared to the four ones formed in 2008

In the second term, in 2013, we observe two main changes: (a) construction sector has changed from being in an independent cluster in 2008 to form a new one together with hostelry, transportation, warehousing and communications sectors; (b) the sector of other social ac- tivities and services to the community, change of cluster joining education and health, veterinary activities and social services.

Last, an increase in the educational level of the new self-employed workers, a greater representation of women and a reduction of job stability take place in all clusters. A general decrease can also be observed in work experience as self-employed (in days) and increased experience in the sector of reference, in terms of number of work episodes.

From these results, we may conclude that there exist 
Table 5. Cluster analysis in 2013: main results.

Table 5A — Sectors by cluster.

\begin{tabular}{|c|c|c|}
\hline Cluster 1 & Cluster 2 & Cluster 3 \\
\hline Manufacturing industry & Hostelry & Education \\
\hline Commerce, vehicles sale and reparation & $\begin{array}{c}\text { Transportation, warehousing and } \\
\text { communication }\end{array}$ & $\begin{array}{l}\text { Health, veterinary activities and social } \\
\text { services }\end{array}$ \\
\hline Financial services & Construction & $\begin{array}{c}\text { Other social activities and community } \\
\text { services }\end{array}$ \\
\hline \multicolumn{3}{|l|}{ Real state and business services } \\
\hline 4 sectors $(40 \%)$ & 3 sectors (30\%) & 3 sectors (30\%) \\
\hline 13.254 self-employees & 7.555 self-employees & 3.350 self-employees \\
\hline$(54.7 \%)$ & $(31.4 \%)$ & $(13.9 \%)$ \\
\hline
\end{tabular}

Table 5B — Profiles of new self-employed.

\begin{tabular}{|c|c|c|c|c|c|}
\hline & VARIABLES & Cluster 1 & Cluster 2 & Cluster 3 & Total \\
\hline V1 & Number of self-employees & 3.298 & 2.518 & 1.117 & 2.410 \\
\hline V2 & Percentage of university graduates & $31.50 \%$ & $12,40 \%$ & $53.90 \%$ & $32.50 \%$ \\
\hline V3 & Percentage of men & $57.90 \%$ & $74.40 \%$ & $36.10 \%$ & $56.30 \%$ \\
\hline V4 & Age as December 31, 2008 & 38.9 & 39.4 & 36.4 & 38.3 \\
\hline V5 & Number of employment episodes & 11.7 & 15.2 & 13.8 & 13.4 \\
\hline V6 & Number of unemployment episodes & 3 & 4.1 & 2.6 & 3.2 \\
\hline V8 & Number of episodes as self-employed & 1.9 & 2.4 & 1.8 & 2 \\
\hline V9 & Number of episodes as employee worker & 9.9 & 12.7 & 12 & 11.4 \\
\hline V12 & $\begin{array}{l}\text { Number of temporary contracts over fixed } \\
\text { contracts }\end{array}$ & 4.3 & 5.5 & 7.2 & 5.5 \\
\hline V13 & Duration of employment episodes (days) & 567.5 & 477.3 & 394.3 & 488.5 \\
\hline V14 & $\begin{array}{l}\text { Duration of unemployment episodes with } \\
\text { benefits (days) }\end{array}$ & 197.3 & 165 & 171.7 & 179.9 \\
\hline V16 & Total experience as self-employee (days) & 1086,8 & 1456.3 & 867.7 & 1131.9 \\
\hline V20 & $\begin{array}{l}\text { Number of labour episodes in the } \\
\text { reference sector }\end{array}$ & 3.6 & 6 & 4.8 & 4.7 \\
\hline
\end{tabular}


Table 5. Cluster analysis in 2013: main results (Continued).

Table 5C - Main characteristics of each cluster.

\begin{tabular}{lccc}
\hline Cluster characteristic & Cluster $\mathbf{1}$ & Cluster $\mathbf{2}$ & Cluster $\mathbf{3}$ \\
\hline Size of the cluster & high & medium & very low \\
Male representation & medium & very high & very low \\
Education level & medium & very low & very high \\
Labour Stability & high & low & low \\
$\begin{array}{l}\text { Experience as self- } \\
\text { employed }\end{array}$ & medium & very high & medium \\
Experience in the sector & low & very high & \\
\hline
\end{tabular}

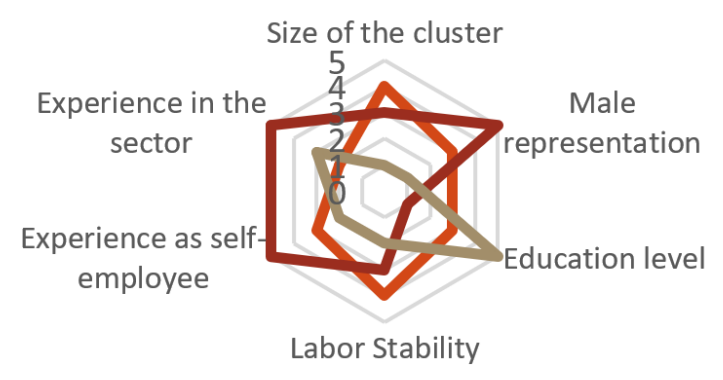

$\longrightarrow$ Cluster $1 \rightleftharpoons$ Cluster $2 \rightleftharpoons$ Cluster 3

Figure 2. Cluster analysis diagram.

Source: Own elaboration based on MCVL year 2013 data.

clusters of self-employed with different socioeconomics and occupational characteristics added to the fact that they have changed during the economic crisis, confirming the second initial hypotheses of this paper.

\section{Conclusions}

The purpose of this paper is to determine if the economic crisis has resulted in significant changes in the socioeconomic and labor profile of the new self-employed in Spain between 2008 and 2013.
Additionally, it intends to analyze if there are homogeneous profiles of new self-employed that allow to set different clusters, and, if so, to check if the characteristics of these clusters have changed during the studied period.

To verify these hypotheses, it has been carried out a very detailed descriptive analysis followed by a Cluster Analysis using the information contained in the Continuous Sample of Working Lives. This methodological approach is relevant for the inves- 
tigation due to two reasons: (a) the grouping of new self-employed workers into a small number of clusters allows to observe which groups of self-employed have been most affected by the crisis as well as the impact on their sociodemographic and labor profiles, which, thus, allows to answer the research questions; (b) The quality and size of the database employed in this research provides great credibility to the results.

Although there are multiple studies in the economic literature on the impact of the economic cycle at the level of self-employment, there is a research gap because these studies do not analyze the effects that the economic cycle has on the socio-economic and labor profile of new self-employed, grouping them in a reduced number of clusters, and using a large volume of reliable data.

The findings of the research allow to conclude in the first place that the economic recession has been accompanied by both a fall in the number of new self-employed workers between 2008 and 2013 and a significant change in their socio-demographic and occupational profile. Several facts confirm this conclusion: (a) the reduction of self-employment in several economic sectors such as construction, manufacturing industry, transportation and warehousing in parallel to the increase in some other as education, commerce and hostelry; (b) A greater representation of women along the years; (c) The rise in the percentage of graduates regardless of their nationality, sector of activity, region of residence or sex as an element which maximizes the opportunities in the labor market, and (d) more labor instability, reflected in an increase in the number of labor episodes, a higher rate of temporary employment and a greater number of work experiences with shorter duration. Therefore, we may conclude that the first hypothesis of this research is confirmed.

In the second place, there is evidence of the existence of several new self-employed clusters, presenting heterogeneous sociodemographic and labor profiles. The analysis is based in 20 variables, grouped in six dimensions: Size of the cluster, male representation, educational level, experience in the sector, experience as self-employed and labor stability. The composition and features of these clusters also evolved in parallel to the changes in the economic cycle, showing in all the cases, an intense increase in the educational level and a reduction in the job stability between 2008 and 2013. Other changes took place according to each cluster. Based on these arguments it may be concluded that the second hypothesis of the research is also confirmed.

The previous results are relevant because they contribute to a better understanding of the current trends of self-employment in Spain - in terms of sociodemographic and occupational profiles - and its relations with the economic cycle. It may also serve of some help to the Spanish economic authorities to understand more efficiently what kind of policies they should adopt to improve the situation of new selfemployed workers in Spain, promoting the entrepreneurial activity according to their different profiles. Some examples of policies are: (a) more and/or better education adapted to the new labor market needs; (b) elimination or reduction of existing legal or financial barriers.; (c) promoting labor market stability in some sectors; (d) incentivizing younger and older people, women, or immigrants. Some other measures may also be adopted like educating the population, entrepreneurs and the public sector in general in entrepreneurial culture, strengthening the entrepreneurial ecosystem with elements that contribute to sharing best practices such as business nurseries, accelerators and coworking companies or promoting the development of laws that support entrepreneurs.

\section{Limitations and Future Research Lines}

This research has some limitations. First, we should consider the restrictions presented by the cluster analysis. It is used as an exploratory technique, descriptive, but not explanatory. Furthermore, it must be considered that the solutions are not unique, insofar as belonging to a cluster, which depends on the chosen procedure, or the variables used.

Second, It should also be noted that the change in the profile of the self-employed is part of a deeper transformation - whose study is out of the scope of this paper - which affects also to the entrepreneurs and to the entrepreneurial ecosystem at a general level, favoring the emergence of new entrepreneurship centers in multiple countries, the appearance of new technological companies that evolve towards specific sectors and the development of financing forms according to the characteristics and needs of the companies. 
With respect to future research lines, this investigation could be extended over the time to analyze future trends of the new self-employed profile or expanded to different territories (other EU countries or Spanish regions for instance). The different economic policies that could be taken to soften the impact of the economic crisis according to the different profiles found could be also analyzed.

\section{References}

Abubakar, A. M., Elrehail, H., Alatailat, M. A., \& Elçi, A. (2019). Knowledge management, decisionmaking style and organizational performance. Journal of Innovation \& Knowledge, 4(2), 104-114.

Barlevy, G. (2007). On the cyclicality of research and development. American Economic Review, 97(4), 1131-1164.

Blanchflower, D. G. (2000). Self-employment in OECD countries. Labour Economics, 7(5), 471-505.

Brünjes, J., \& Diez, J. R. (2013). 'Recession push and 'prosperity pull entrepreneurship in a rural developing context. Entrepreneurship \& Regional Development, 25(3-4), 251-271.

Cáceres Ruiz, J. I., \& Rodríguez, V. F. (2009). Crisis y trabajo autónomo en España. Documentación laboral, (85), 33-50.

Calleja Crespo, D. (2013) Los emprendedores, motor de la economía europea. [Entrepreneurs, engine of the European economy]. Newsletter ICO, 6.

Carrasco, R. (1999). Transitions to and from self-employment in Spain: an empirical analysis. Oxford Bulletin of Economics and Statistics, 61(3), 315341.

Carree M. A., \& Thurik A. R. (2010) The impact of entrepreneurship on economic Growth. In Z. Acs, \& D. Audretsch. (Eds.), Handbook of entrepreneurship research. International handbook series on entrepreneurship, vol. 5 (pp. 437-471). Springer.

Congregado, E., Golpe, A. A., \& Parker, S. C. (2012). The dynamics of entrepreneurship: hysteresis, business cycles and government policy. Empirical Economics, 43(3), 1239-1261.

CSWL (2008). Muestra Continua de Vidas Laborales 2008. Ministerio de Trabajo y Asuntos Sociales. [Continuous Sample of Working Lives 2008. Ministry of labor and social affairs ].

CSWL (2013) Muestra Continua de Vidas Laborales 2013. Ministerio de Trabajo y Asuntos Sociales. [Continuous Sample of Working Lives 2013. Ministry of labor and social affairs ].
Cuadrado, J., Iglesias, C., \& Llorente, R. (2005). El empleo autónomo en España: factores determinantes de su reciente evolución [Self-employment in Spain: Determining factors in its recent evolution]. CIRIEC-España, 52, 175-200.

Cuadrado, J., Iglesias, C., \& Llorente, R. (2004). Empleo autónomo y empleo asalariado. Análisis de las características y comportamiento del autoempleo en España. [Self employment and employment. Analysis of the characteristics and behavior of self-employment in Spain]. Colección Informes y Estudios. MTAS.

Cueto Iglesias \& B. y Taboada González, I. (2004). Un análisis comparativo de los programas de fomento del empleo autónomo en España. [A comparative analysis of self-employment promotion programs in Spain]. Boletín Económico de ICE, 2819, 9-18.

Dunn, T., \& Holtz-Eakin, D. (2000). Financial capital, human capital, and the transition to self-employment: Evidence from intergenerational links. Journal of Labor Economics, 18(2), 282-305.

Eckhardt, J. T. \& Shane, S. A. (2003). Opportunities and entrepreneurship. Journal of Management, 29(3), 333-349.

Fairlie, R. W. (1999). The absence of the AfricanAmerican owned business: An analysis of the dynamics of self-employment. Journal of Labor Economics, 17(1), 80-108.

Filipetti, A., \& Archibugy, D. (2010). Innovation in times of crisis: national systems on innovation, structure, and demand. Research Policy, 40(2), 179-192.

Francois, P., \& Lloyd-Ellis, H. (2003). Animal spirits through creative destruction. American Economic Review, 93(3), 530-550.

Fritsch, M., \& Kritikos, A. S. (2016). Entrepreneurship and the Business Cycle. CESIFO DICE Report, 14(3), 24-28.

García-Fernández, J., Gálvez-Ruiz, P., Vélez-Colon, L., Ortega-Gutiérrez, J., \& Fernández-Gavira, J. (2018). Exploring fitness centre consumer loyalty: differences of non-profit and low-cost business models in Spain. Economic Research-Ekonomska Istraživanja, 31(1), 1042-1058.

GEM (2016). Global Entrepreneurship Monitor España 2015. Universidad de Cantabria, vol. 22. Retrieved from https://www.gemconsortium.org/ report/gem-spain-2015-report

Grant, D. S. (1996). The political economy of new business formation across the American states, 19701985. Social Science Quarterly.

Guadaño, J. F., Martín, S., \& de las Vacas, G. L. P. 
(2010). Retos del trabajo autónomo para afrontar la crisis económico-financiera. Economistas, 28(124), 99-113.

Haltiwanger, J., Scarpetta, S., \& Schweiger, H. (2010). Cross-country differences in job reallocation: the role of industry, firm size and regulations. Labour Economics, 26, 11-25.

Hamilton, B. H. (2000). Does entrepreneurship pay? An empirical analysis of the returns to self-employment. Journal of Political Economy, 108(3), 604-631.

Hundt, C., \& Sternberg, R. (2014). How did the economic crisis influence new firm creation? Jahrbücher für Nationalökonomie und Statistik, 234(6), 722-756.

INE-DIRCE. (2016). Directorio Central de Empresas, explotación estadística. [Central Business Directory, statistical exploitation].

Instituto Nacional de Estadística. Retrieved from http://www.ine.es/dynt3/inebase/es/index. htm? padre $=51 \& \mathrm{dh}=1$

INE-EPA. (2016). Encuesta de Población Activa, explotación estadística. [Labour Force Survey, statistical exploitation].

Instituto Nacional de Estadística (2008). Empresas por estrato de asalariados y condición jurídica [Companies by employee stratum and legal status]. Retrieved from http://www.ine.es/dyngs/INEbase/ es/operacion.htm?c=Estadistica_C\&cid=1254736 $176918 \&$ menu $=$ resultados\&idp $=1254735976595$

INE. (2018). Instituto Nacional de Estadística. Annual Spanish National Accounts: main aggregates. Retrieved from https://www.ine.es/dyngs/INEbase/ en/operacion.htm?c=Estadistica_C\&cid $=125473$ 6177057\&menu $=$ resultados\&idp $=1254735576581$

Klapper, L., \& Love, I. (2011). The impact of the financial crisis on new firm registration. Economics Letters, 113(1), 1-4.

Knight, F. (1921). Risk, uncertainty and profit. Houghton.

Koellinger, P. D., \& Roy Thurik, A. (2012). Entrepreneurship and the business cycle. Review of Economics and Statistics, 94(4), 1143-1156.

Kolvereid, L., \& Isaksen, E. (2006). New business start-up and subsequent entry into self-employment. Journal of Business Venturing, 21(6), 866885.

Konon, A., Fritsch, M., \& Kritikos, A. S. (2018). Business cycles and start-ups across industries: An empirical analysis of German regions. Journal of Business Venturing, 33(6), 742-761.

Lee, S. (2018). Growth, profits and R\&D in- vestment. Economic Research-Ekonomska Istraživanja, 31(1), 607-625.

Gobierno de España. (2007). Ley 20/2007, de 11 de julio, del estatuto del trabajo autónomo [Law 20/2007, of July 11, on the statute of self-employment]. Retrieved from https://www.boe.es/buscar/act. php?id=BOE-A-2015-11430\&p=20151024\&tn=2.

Gobierno de España. (2013). Ley 14/2013, de 27 de septiembre, de apoyo a los emprendedores y su internacionalización. [Law 14/2013, of September 27 , on support for entrepreneurs and their internationalization]. Retrieved from https://www.boe. es/buscar/ act.php?id=BOE-A-2013-10074.

Gobierno de España. (2015). Ley 31/2015, de 9 de septiembre, por la que se modifica y actualiza la normativa en materia de autoempleo y se adoptan medidas de fomento y promoción del trabajo autónomo y de la Economía Social. [Law 31/2015, of September 9, which modifies and updates the regulations on self-employment and adopt measures to promote self-employment and the Social Economy]. Retrieved from https://www.boe.es/ buscar/act.php?id=BOE-A-2015-9735.

Gobierno de España. (2017). Ley 6/2017, de 24 de octubre, de Reformas Urgentes del Trabajo Autónomo. [Law 6/2017, of October 24, on Urgent Reforms of self-employment]. Retrieved from https://www.boe.es/diario_boe/ txt.php?id=BOEA-2017-12207.

Maroto Acín, J. A. (2006). Situación socioeconómica del trabajo autónomo. Visión general. [Socioeconomic situation of self-employment. General overview.] In F. S. Ramos, \& José María Herranz de la Casa, (Eds.) El trabajo autónomo en España (pp. 23-50). Universidad Católica de Ávila.

Megeirhi, H. A., Kilic, H., Avci, T., Afsar, B., \& Abubakar, A. M. (2018). Does team psychological capital moderate the relationship between authentic leadership and negative outcomes: an investigation in the hospitality industry. Economic Research-Ekonomska Istraživanja, 31(1), 927-945.

McCarthy, D. J., Puffer, S. M., \& Lamin, A. (2018). Entrepreneurial orientation in a hostile and turbulent environment: risk and innovativeness among successful Russian entrepreneurs. European Journal of International Management, 12(1/2), 191-221.

Navarro, J.R., Cabello, C. y Medina, R. (2014); Valoración de la Ley de Emprendedores Española. [Assessment of the Spanish Entrepreneurs Law]. Global Entrepreneurship Monitor, Informe GEM España 2013, 103-122.

Miller, D. (1983). The correlates of entrepreneurship in 
three types of firms. Management science, 29(7), $770-791$.

MTMSS (2018) Ministerio de Trabajo, migraciones y seguridad social. [Ministry of Labor, Migration and Social Security]. Retrieved from http://www. mitramiss.gob.es/es/sec_trabajo/autónomos/ economía-soc/autónomos/estadística/index.htm.

Öberg, C. (2019). The role of business networks for innovation. Journal of Innovation \& Knowledge, 4(2), 124-128.

Parker, S. C. (2018). The economics of entrepreneurship. Cambridge University Press.

Parker, S. C., Congregado, E., \& Golpe, A. A. (2012). Is entrepreneurship a leading or lagging indicator of the business cycle? Evidence from UK self-employment data. International Small Business Journal, 30(7), 736-753.

Parker, S. C., Congregado, E., \& Golpe, A. A. (2012). Testing for hysteresis in entrepreneurship in 23 OECD countries. Applied Economics Letters, 19(1), 61-66.

Pérotin, V. (2006). Entry, exit, and the business cycle: Are cooperatives different? Journal of Comparative Economics, 34(2), 295-316.

Rampini, A. A. (2004). Entrepreneurial activity, risk, and the business cycle. Journal of Monetary Economics, 51(3), 555-573.

Román, C., Congregado, E., \& Millán, J. M. (2013). Start-up incentives: Entrepreneurship policy or active labour market programme? Journal of Business Venturing, 28(1), 151-175.

Roura, J. R. C., Fernández, C. I., \& Heras, R. L. (2005). El empleo autónomo en España: factores determinantes de su reciente evolución. [Self-employment in Spain: determining factors of its recent evolution].

Ryan, J. C., \& Daly, T. M. (2019). Barriers to innovation and knowledge generation: The challenges of conducting business and social research in an emerging country context. Journal of Innovation \& Knowledge, 4(1), 47-54.

Sánchez Solano, E. (2006). El autoempleo como medida de la política activa de empleo. El autoempleo en España. In F. Salinas Ramos, J. M. Herranz de la Casa (Eds.), El trabajo autónomo en España (pp. 61-96). Universidad Católica de Avila.

Sanders, J. M., \& Nee, V. (1996). Immigrant self-employment: The family as social capital and the value of human capital. American Sociological Review, 61(2) 231-249.

Sentana, E., Gonzalez, R., Gasco, J., \& Llopis, J. (2018). New strategies to measure and strengthen the so- cial role of business incubators: their application to a Spanish region. European Journal of International Management, 12(5-6), 536-553.

Schumpeter, J. A., \& Opie, R. (1934). The theory of economic development; an inquiry into profits, capital, credit, interest, and the business cycle. Harvard University Press. Schumpeter, J. A. (1942). Capitalism, Socialism and Democracy. Harper.

Schweitzer, M. E., \& Shane, S. (2016). The ins and outs of self-employment: An estimate of business cycle and trend effects. Federal Reserve Bank of Cleveland (Working Paper No. 16-21).

Simón-Moya, V., Revuelto-Taboada, L., \& Ribeiro-Soriano, D. (2016). Influence of economic crisis on new SME survival: reality or fiction? Entrepreneurship \& Regional Development, 28(1-2), 157-176.

Svaleryd, H. (2015). Self-employment and the local business cycle. Small Business Economics, 44(1), 55-70.

Stevenson, H.H., \& Jarillo, J.C. (1990). A paradigm of entrepreneurship: Entrepreneurial management. Strategic Management Journal, 11, 17-27.

Torres, A. J. (2018). El impacto de la crisis económica sobre el perfil de los trabajadores autónomos en España: una aproximación a través de la muestra continua de vidas laborales. [The impact of the economic crisis on the profile of self-employed in Spain: an approach through the continuous sample of working lives] [Unpublished doctoral dissertation]. Universidad Rey Juan Carlos.

Veciana Vergés, J. M. (1999). Creación de empresas como programa de investigación científica. [Creation of companies as a scientific research program]. Revista Europea de Dirección y Economía de la empresa, 8(3), 11-36.

Williams, N., \& Vorley, T. (2015). The impact of institutional change on entrepreneurship in a crisis-hit economy: the case of Greece. Entrepreneurship \& Regional Development, 27(1-2), 28-49. 